\title{
A DEVOLUÇÃO DO BEM PÚBLICO SUBTRAÍDO E A DESCARACTERIZAÇÃO DO ATO DE IMPROBIDADE ADMINISTRATIVA
}

\author{
Wellington Henrique Rocha de Lima ${ }^{1}$ \\ Jussara Suzi Assis Borges Nasser Ferreira ${ }^{2}$
}

\section{RESUMO:}

O presente artigo tem como escopo a análise da devolução do bem público subtraído para a descaracterização do ato de improbidade administrativa com a utilização da metodologia analítica dedutiva de referências bibliográficas, de decisões judiciais e jurisprudenciais. A problematização da investigação reside em perquirir se há responsabilização em ressarcir de forma integral o dano causado e a perda dos bens ou valores acrescidos ilicitamente ao patrimônio do agente. O texto é construído de forma narrativa descritiva e busca confirmar a hipótese de que não há ato de improbidade se não houver acréscimo do bem público ao patrimônio do particular.

PALAVRAS-CHAVE: Bem subtraído; Ato de improbidade; Devolução; Descaracterização; Lei de Improbidade Administrativa.

\section{THE RETURN OF SUBTRACTED PUBLIC GOODS AND THE MISCHARACTERIZATION OF THE ADMINISTRATIVE IMPROBITY ACT}

\begin{abstract}
:
This article is to analyze the return of the subtracted public good for the mischaracterization of the act of administrative improbity using the deductive analytical methodology of bibliographic references, judicial and jurisprudential decisions. The problem with the investigation lies in investigating whether there is a responsibility to fully compensate the damage caused and the loss of assets or values unlawfully added to the agent's assets. The text is constructed in a descriptive narrative manner and seeks to confirm the hypothesis that there is no act of improbity if there is no addition of the public good to the private property.
\end{abstract}

KEYWORDS: Commonweal subtracted; Act of improbity; Devolution; Mischaracterization; Administrative Improbity Law.

\section{INTRODUÇÃO}

\footnotetext{
${ }^{1}$ Doutorando em Direito pela Universidade de Marília - UNIMAR. Mestre em Direito Processual e Cidadania pela Universidade Paranaense - UNIPAR. Professor da Graduação da UNIGRAN e UEMS. Advogado. Endereço postal: Avenida Sérgio Maciel, 1145, centro - Juti - MS. E-mail: wellington.lima@ unigran.br

${ }^{2}$ Doutora em Direito pela Pontifícia Universidade Católica de São Paulo - PUC. Mestre em Direito pela Universidade Estadual de Londrina - UEL. Professora do PPGD - UNIMAR e UNIPAR. Advogada. Endereço postal: Av. Ayrton Senna da Silva, 1055 sala 1202 - Londrina - PR. E- mail: jussara@bflaw.adv.br
} 
Como se caracteriza o prejuízo ao erário? As sanções de ressarcimento integral do dano ou a perda dos bens e valores acrescidos ao patrimônio devem ocorrer sempre que houver a caracterização do ato de improbidade? A devolução do bem público descaracteriza o ato de improbidade? Havendo a caracterização do ato, imperioso é o ressarcimento ao erário quando o bem for restituído?

Tais perquirições norteiam a investigação necessária, pontuando a interpretação das questões envolvendo a persecução dos agentes ímprobos por meio da Lei sob n. ${ }^{\circ} 8.429$ de 1992, a Lei de Improbidade Administrativa.

Pelo método dedutivo analítico, traça-se conceituação básica por meio dos referenciais teóricos e legislativos pátrios, destacando a possibilidade de descaracterização do ato de improbidade que cause prejuízo ao erário quando houver a devolução do bem subtraído para a Administração Pública. De maneira descritiva argumentativa são definidas as hipóteses para resolutividade das demandas envolvendo o ato de improbidade descrito no Art. 10, I, da lei citada.

O texto é construído de forma narrativa descritiva e busca confirmar a hipótese de que não há ato de improbidade se não houver acréscimo do bem público ao patrimônio do particular. Em contrapartida, com base na jurisprudência do Superior Tribunal de Justiça, verifica-se a problemática aludida, bem como a fundamentação doutrinária e judicial das hipóteses lançadas.

A Lei de Improbidade Administrativa, sob n. ${ }^{\circ}$ 8.429, de 1992, não trata de todo ato de ilegalidade, mas de atos ímprobos, reconhecidos como ilegalidades qualificadas, ao passo que não é todo ato que se considera improbidade administrativa. Também se verifica na presente análise, a possibilidade da não aplicação da referida lei em todos os atos realizados, haja vista todas as circunstâncias periféricas ao ato que devem ser levadas em consideração.

Ressarcir o erário quando o bem público subtraído for devolvido de forma voluntária ou até mesmo contenciosa pode ensejar no enriquecimento ilícito da Administração Pública. Por outro lado, de maneira superficial, é inviável que o agente que comete ato de improbidade não seja punido quando os bens públicos são vilipendiados.

Nessa esteira, o artigo se organiza em três seções. Na primeira, verifica-se o ato de improbidade em sentido geral, com breves aportes; na segunda seção, analisa-se o ato de improbidade que cause prejuízo/dano ao erário, especificamente no ato de subtração do bem público; e, na terceira seção, investiga-se o ato de devolução do bem subtraído e seus efeitos. 


\section{O ATO DE IMPROBIDADE ADMINISTRATIVA: APORTES GERAIS}

Em aportes gerais, a conceituação de ato de improbidade administrativa é incessantemente discutida pela doutrina. Em diversos julgamentos nas instâncias superiores, sua natureza jurídica é rotineiramente suscitada e, desde a promulgação da Lei de Improbidade que dispõe de tais atos, a divergência ainda permeia.

Os atos jurídicos públicos possuem características próprias, evidentemente diferenciando-os dos atos jurídicos privados, pois os públicos possuem normatização jurídica peculiar, sobretudo pela preponderância do interesse público neles presentes. Dentre tais peculiaridades, em sentido lato, é possível verificar que prevalece o que está expresso e não somente a intenção das partes, diferentemente do direito privado, regido pelo princípio do autorregramento, o ato jurídico público deve respeitar os limites definidos em lei (MELLO, 2019).

A Lei n. ${ }^{\circ}$ 8.429, de 1992, dispõe sobre as sanções aplicáveis aos agentes públicos nos casos de enriquecimento ilícito no exercício de mandato, cargo, emprego ou função na administração pública. Os atos de improbidade administrativa praticados por qualquer agente público, servidor ou não, contra a Administração Pública direta, indireta, fundacional de qualquer dos Poderes da União, em destaque de empresa incorporada ao patrimônio público ou de entidade para cuja criação ou custeio o erário haja concorrido ou concorra com mais de cinquenta por cento do patrimônio ou da receita anual, serão punidos na forma dessa lei (Art. $\left.1^{\circ}\right)($ BRASIL, 1992).

Cumpre destacar que tal repressão a esses atos encontra respaldo constitucional e somente será possível a cassação dos direitos políticos, cuja perda ou suspensão se dará nos casos de improbidade administrativa, dentre outros descritos no próprio texto constitucional (Art. 15, V) (BRASIL, 1988).

Com efeito, dispõe o texto constitucional que "os atos de improbidade administrativa importarão a suspensão dos direitos políticos, a perda da função pública, a indisponibilidade dos bens e o ressarcimento ao erário, na forma e gradação previstas em lei (8.429 de 1992), sem prejuízo da ação penal cabível” (BRASIL, 1988).

Dispõe o Art. 2. ${ }^{\circ}$ da Lei de Improbidade Administrativa que é agente público: "todo aquele que exerce, ainda que transitoriamente ou sem remuneração, por eleição, nomeação, 
designação, contratação ou qualquer outra forma de investidura ou vínculo, mandato, cargo, emprego ou função nas entidades mencionadas no artigo anterior” (BRASIL, 1992). Como também será aplicada a mesma lei para aquele que, mesmo não sendo agente público induza ou concorra para a prática do ato de improbidade ou dele se beneficie sob qualquer forma, direta ou indireta (Art. 3. ${ }^{\circ}$ ) (BRASIL, 1992).

A improbidade administrativa constitui violação ao princípio constitucional da moralidade, o qual é basilar da Administração Pública, bem como de todas as regras e normas do ordenamento público/privado. Nesse diapasão, a improbidade administrativa pode ser considerada uma imoralidade administrativa qualificada (GAJARDONI et al., 2014).

Para que haja caracterização da improbidade administrativa é essencial a existência de ilicitude no ato realizado pelo agente público ou aquele que tem relação com a Administração Pública, levando em consideração tanto a imoralidade, quanto a ilegalidade desse ato (MARTINS JÚNIOR, 2001).

É possível verificar que cometem ato de improbidade aqueles agentes que não se enquadram em suas funções e não compreendem que a vida pública é exercida como sacerdócio de servidão ao interesse de toda coletividade, e estes que não agem com lealdade, dentro da legalidade, da honestidade e com destreza para com os bens públicos, incorrem no desserviço aos cidadãos, caminhando para ser intitulado como agente público ímprobo, desonesto ou corrupto (LIMA; FERREIRA, 2019).

Em sequência, conforme análise legal, é possível vislumbrar que o ato de improbidade estará configurado quando aquele agente público ou não, que incorra na não observância dos princípios da legalidade, impessoalidade, moralidade, publicidade e da eficiência (Art. 4. ${ }^{\circ}$ ); ou que cause lesão ao patrimônio público por ação ou omissão, dolosa ou culposa, do agente ou de terceiros (Art. 5. ${ }^{\circ}$ ); ou que obtenha enriquecimento ilícito (Art. 6..$^{\circ}$ ) ou qualquer ação ou omissão que conceda, aplique ou mantenha benefício financeiro ou tributário contrário ao disposto nas leis específicas, cumulativamente ou não (BRASIL, 1992).

Dos atos em específico, a Lei de Improbidade Administrativa traz um rol de quatro atos que constituem improbidade administrativa, quais sejam, os atos que importam em enriquecimento ilícito (Art. 9.9); os que causem prejuízo ao erário (Art. 10); os de concessão ou aplicação indevida de benefício financeiro ou tributário (Art. 10-A) e os atos que atentam contra os princípios da Administração Pública (Art. 11) (BRASIL, 1992). 
Os referidos dispositivos legais tentam proteger a Administração Pública contra os administradores ímprobos, ou seja, os maus administradores, os quais desejaram se tornar agentes públicos apenas visando ao enriquecimento ilícito, como por exemplo (FERNANDES; SILVA, 2018). No mesmo sentido, o diploma legal de combate à improbidade administrativa visa à sanção daqueles que mantêm relação jurídica com o Poder Público e não agem com lisura, probidade, boa-fé, legalidade, dentre outros.

Em respeito ao Estado Democrático de Direito, é necessário que haja mecanismos hábeis para o combate de casos e atos de corrupção, bem como de atos de improbidade administrativa que assolam a Administração Pública e tanto prejudicam o país. Nesse sentido, por meio de dispositivos legais, procura-se coibir os atos que resultem em graves casos de ineficiência funcional e corrupção sistêmica (AMÉRICO; FREITAS, 2019).

Quando se trata de ato de improbidade administrativa, deve-se levar em consideração que não são apenas atos de inabilidade dos agentes públicos, rotineiros de repartições ou órgãos públicos, os quais são suscetíveis de apreciação disciplinar, mas aqueles atos que agridem moral e materialmente os princípios e parâmetros constitucionais que regem a Administração Pública, quer dizer, a ordem pública estabelecida (FAZZIO JÚNIOR, 2016).

A improbidade administrativa que possui previsão constitucional especificamente no Art. 37, § 4. ${ }^{\circ}$ da Constituição Federal (BRASIL, 1988), e é regulamentada pela Lei n. ${ }^{\circ} 8.429$ (BRASIL, 1992), trouxe novo panorama de persecução para os atos que afrontam a Administração Pública, haja vista, hodiernamente, que se deve verificar, em primeiro lugar, a incompatibilidade da conduta praticada com os princípios regentes da atividade estatal. A norma, consubstanciada de regras e princípios, haverá de ser observada, sendo sua violação o principal prisma de identificação dos atos de improbidade, porque os de natureza administrativa devem ser punidos independentemente da efetiva ocorrência de dano ao erário (GARCIA, 2014).

Nesse diapasão, a conduta praticada pelo agente público deve conter desonestidade, má-fé, falta de probidade no trato da coisa pública; e, agindo dessa forma, o agente estará violando o princípio da probidade administrativa (honestidade, decência, honradez) na gestão dos negócios públicos. Improbidade administrativa está muito além da mera irregularidade administrativa, mas na ilegalidade qualificada. Contudo, somente nas hipóteses de dano ao erário (Art. 10) poderá ser suficiente para sua configuração a ação ou omissão ilícita culposa, 
ou seja, o descumprimento inescusável de dever de ofício, com propósito desonesto, causador de involuntário dano ao erário (PAZZAGLINI FILHO, 2018).

Em apartado, conforme problemática proposta para análise, verifica-se, no presente artigo, os atos de improbidade que causem prejuízo ao erário e a possível devolução do bem público nos casos de subtração e, diante disso, ocorra a descaracterização do ato de improbidade administrativa ou não haja a sanção de ressarcimento integral do dano.

$\mathrm{Na}$ seção a seguir, busca-se/investiga-se a compreensão do que é prejuízo/dano ao erário e as características, requisitos e sanções/penalidades aos agentes que incorrem na prática desse ato contra a Administração Pública de acordo com a Lei de Improbidade Administrativa de 1992.

\section{A CONDUTA E A DESCARACTERIZAÇÃO DO ATO DE IMPROBIDADE ADMINISTRATIVA: O DANO AO ERÁRIO}

Conforme já aludido anteriormente, a Lei sob n. ${ }^{\circ}$ 8.429, de 1992, regulamenta os atos de improbidade administrativa, bem como estabelece os requisitos para configuração, e sanções pelo cometimento dos atos ímprobos descritos nos artigos 9. ${ }^{\circ}, 10,10-\mathrm{A}$ e 11 da referida lei.

Como objeto da presente análise, dispõe o Art. 10 da Lei n. ${ }^{\circ}$ 8.429, de 1992, que constitui ato de improbidade administrativa causando lesão ao erário "qualquer ação ou omissão, dolosa ou culposa, que enseje perda patrimonial, desvio, apropriação, malbaratamento ou dilapidação dos bens ou haveres das entidades referidas no art. $1^{\circ}$ desta lei [...]” (BRASIL, 1992). Essa previsão legislativa carrega consigo mais vinte e um incisos, os quais trazem as notas facilitação, permissão, doação, realização, concessão, frustação, ação, negligência, ordem, celebração, dentre outros. ${ }^{3}$

De forma isolada, o Art. 10-I merece destaque, haja vista ser o principal objetivo do presente artigo, ou seja, verificar como a incorporação no patrimônio privado de pessoa física ou jurídica, de bens, rendas, verbas ou valores integrantes do acervo patrimonial das entidades mencionadas no Art. $1^{\circ}$ da Lei de Improbidade Administrativa se torna ato de improbidade administrativa por dano ao erário (BRASIL, 1992).

\footnotetext{
${ }^{3}$ A descrição de todos os incisos não é objeto da presente análise, a qual está consubstanciada na devolução de bens subtraídos como forma de descaracterização do ato de improbidade administrativa.
} 
Entrementes, o dano ao erário (Art. 10) configura improbidade quando o agente viola os princípios norteadores de sua atividade, já que o prejuízo financeiro encontra-se ínsito em muitas atividades estatais, em especial as de cunho econômico, o simples ato de violação, descumprimento, desonestidade configura dano ao erário (GARCIA, 2014).

Para que seja configurado o ato de improbidade de dano ao erário não é necessária a cumulação com o enriquecimento ilícito do agente público ou do terceiro, sendo somente a comprovação do elemento subjetivo (dolo ou culpa) e que haja nexo causal entre a ação/omissão e a respectiva lesão ao erário. Por outro lado, é possível que haja a descaracterização do dano ao erário, se não houver prejuízo econômico aos cofres públicos (NEVES; OLIVEIRA, 2019).

Noutro giro, tece-se que não se deve utilizar a legislação de combate à improbidade administrativa para sanção do agente público que se utiliza da impressora da repartição pública para algumas cópias particulares - respeitadas as devidas proporções é claro (LIMA; FERREIRA, 2019). Ao encontro dessa ideia está a que deverá sofrer sanção pela retro referida lei aquele agente público ou terceiro que furta resmas de folha sulfite.

Em uma intelecção lógica, os atos/verbos descritos nos incisos dos artigos da Lei de Improbidade Administrativa não são reconhecidos como numerus clausus, ou seja, não é um rol taxativo, mas sim exemplificativo, podendo existir, portanto, a prática de atos que não estejam individualizados nos referidos incisos, mas que se enquadrem na conduta descrita no caput de cada artigo (BARBOSA, 2016).

Nesse sentido, a caracterização do ato de improbidade administrativa que cause dano ao erário, quando não se pressupõe ter havido o enriquecimento ilícito (quando houver não há dúvida, em tese), levar-se-á em consideração a prática da conduta que, por qualquer razão, mostra-se jurídica e patrimonialmente ilícita e danosa ao Estado (AMORIM JUNIOR, 2017). Não há então, a necessidade de comprovação de lucro ou bônus por parte do agente causador do ato.

A configuração do presente ato de improbidade administrativa exige a presença da conduta dolosa ou culposa do agente, do comportamento ilícito que acarrete lesão ao erário ou perda patrimonial de bens ou haveres e a existência de nexo causal entre o dano do patrimônio público e o exercício funcional (MIRANDA, 2012).

Uma demanda fundada na Lei de Improbidade Administrativa tem como objetivos, dentre outros, visar à declaração de ocorrência de improbidade administrativa na prática de 
determinado ato e, consequentemente, à desconstituição desse ato; à condenação dos agentes públicos e à condenação dos réus a indenizar as pessoas indicadas no Art. 1. ${ }^{\circ}$ (DINAMARCO, 2001).

Firma-se, portanto, o entendimento de que o prejuízo/dano causado ao erário não depende de enriquecimento ilícito do agente público ou do privado que mantém relações negociais com a Administração Pública. Havendo nexo de causalidade da ação/omissão, dolosa ou culposa do agente, resta caracterizado o ato de improbidade administrativa, observando que, não necessariamente, deve existir prejuízo financeiro, ou seja, a subtração de bens ou recursos em pecúnia.

O prejuízo ao erário pode estar fundado na utilização de "bens, rendas, verbas ou valores integrantes do acervo patrimonial das entidades mencionadas no Art. 1. ${ }^{\text {" }}$ da Lei de Improbidade Administrativa, sem a observância das formalidades legais ou regulamentares aplicáveis à espécie (Art. 10, II) (BRASIL, 1992). A simples utilização, sem a devida legitimidade para, pode ensejar o prejuízo ao erário.

Aquele que comete ato de improbidade administrativa, por causar lesão/dano/prejuízo ao erário responde nos termos do Art. 12 pelas penas que podem ser aplicadas isoladas ou cumulativamente, independentemente das sanções penais, civis e administrativas, ao ressarcimento integral do dano causado e perda dos bens ou valores acrescidos ilicitamente ao patrimônio. Afluindo em tais circunstâncias, o agente público estará sujeito à perda da função pública, à suspensão dos direitos políticos de cinco a oito anos, ao pagamento de multa civil de até duas vezes o valor do dano e à proibição de contratar com o Poder Público, receber benefícios ou incentivos fiscais ou creditícios, direta ou indiretamente (Art. 12, II) (BRASIL, 1992).

Para a fixação das penas, o juiz deve levar em consideração a extensão do prejuízo causado ao erário, como para as demais práticas de atos de improbidade administrativa descritos na legislação específica, bem como para outras previsões do conserto jurídico pátrio.

Evidentemente que a Lei de Improbidade Administrativa se mostra como grande avanço para a sanção dos agentes ímprobos que visam às relações com a Administração Pública; entretanto, como exposto anteriormente, as sanções descritas no artigo 12 da referida lei, se mostram um tanto quanto abrangentes, o que pode ser temerário se o seu uso não for dosado. Assim, não pode a lei se transformar sob o pálio da defesa social e da proteção à 
ordem pública, em um aparato bélico repressivo que avilte a dignidade do imputado (CAPEZ, 2015).

Entretanto, pode ser condenado aquele que comete ato que se caracteriza prejuízo ao erário e restitui os bens subtraídos? Pode ainda sofrer sanções aquele agente público que ressarce o erário de forma voluntária e eficaz? Havendo a restituição do bem subtraído, não poderia o agente responder disciplinarmente por outros meios? A restituição do bem subtraído pode ter efeitos para a verificação da responsabilidade pela reparação integral do prejuízo?

Diante dos questionamentos acima suscitados que se investiga, anota-se a possibilidade da descaracterização ou não do ato de improbidade administrativa pela restituição de bens subtraídos ou pela desobrigação de reparação integral do prejuízo, quando houver a restituição.

\section{O RESSARCIMENTO OU A RESTITUIÇÃO DOS BENS À ADMINISTRAÇÃO PÚBLICA PELA PESSOA QUE PRATICOU A CONDUTA ÍMPROBA}

Aqueles que comentem ato de improbidade administrativa, conforme descrito na Lei sob n. ${ }^{\circ} 8.429$ de 1992, responderão de forma cível, criminal e administrativa, independentemente das sanções descritas na referida lei. Nos casos dos atos de improbidade que causem prejuízo ao erário, qualquer ação ou omissão, dolosa ou culposa ensejaram nas penalidades.

As penalidades pelo ato ímprobo que cause prejuízo ao erário se consubstanciam essencialmente no ressarcimento integral do dano e perda dos bens ou valores acrescidos ilicitamente ao patrimônio e, enquadrando-se nesses, sofreram as demais sanções conforme descreve a legislação.

Entrementes, caso haja devolução do bem subtraído, pode o sujeito ativo (o agente público ou não) do ato de improbidade ser condenado ao ressarcimento integral do dano? A restituição voluntária ou compulsória faz desaparecer o ato de improbidade que gerou o dano ao erário?

Em que pese a sociedade tenha consigo a ideia de que somente responde por ato de improbidade, e que é ímprobo, imoral, desonesto ou corrupto, sejam os políticos, todos os agentes públicos ou agentes privados que tenham relações com a Administração Pública estão sujeitos à reprimenda da legislação de combate a improbidade. 
A criminalização da política brasileira e os altos índices de corrupção trouxeram instabilidade para a democracia nacional, pondo em xeque toda a ordem pública, ao passo que abalou e abala o Estado Democrático de Direito. Por vezes, os anseios de pôr fim às irregularidades e ilegalidades cometidas, os brasileiros pedem o fim da democracia. A corrupção atenta contra o próprio princípio democrático, sobretudo pela sedimentação da ideia de que todo mandatário do povo é corrupto e desonesto, o que representa a semente indesejada de medidas antidemocráticas (GARCIA, 2014).

Nesse diapasão, nem toda ilegalidade deve ser recepcionada como ato ímprobo, nem toda mera irregularidade, inabilidade ou ignorância dos gestores públicos, dos agentes públicos ou privados. Não é demasiado lembrar que a Lei de Improbidade Administrativa é utilizada para penalizar o administrador desonesto e não o inábil. A incompetência pode dar origem a outro tipo de responsabilização, mas nunca à incidência da lei de improbidade. $O$ incompetente pode ser taxado popularmente de burro, mas jamais de safado (HARGER, 2015).

Não obstante, verifica-se a possibilidade de conversão da persecução pelo ato de improbidade em responsabilização administrativa quando houver o ressarcimento integral do dano em caso de prejuízo ao erário ou devolução do bem subtraído. Em análise específica, a primeira turma do Superior Tribunal de Justiça, recentemente, decidiu quanto a essa (in) possibilidade aduzida no presente artigo.

Trata-se de uma ação de improbidade administrativa ajuizada pelo Ministério Público Federal, em desfavor de dois funcionários públicos da Empresa Brasileira de Correios e Telégrafos - ECT. O agente público "X", tendo se valido desta condição para facilitar o desvio de 40 (quarenta) caixas de papel offset, tamanho A-4, da marca CHAMEX, contratando terceiro para tirar referido material da ECT, para quem forneceu fardamento da referida empresa pública e adesivos com o logotipo desta. Fora imputado a este réu as condutas previstas no Art. 9. ${ }^{\circ}$ XI e XII; no Art. 10, I e XII e Art. 11, todos da Lei n. ${ }^{\circ}$ $8.429 / 1992$.

O Ministério Público Federal alegou que, em relação ao réu "Y", este foi contratado por " $\mathrm{X}$ " para proceder à subtração de 40 (quarenta) caixas de papel do almoxarifado da ECT, o que fez realizando o carregamento dos materiais e o transporte dos mesmos até a Papelaria "V" Distribuidora de Produtos Ltda., onde os mesmos seriam descarregados. 
Alegou, ainda, em relação ao réu "Z”, que este também concorreu para a subtração das 40 (quarenta) caixas de papel, o que fez disponibilizando o veículo modelo Kombi, de sua propriedade, para o transporte do mencionado material, tendo, inclusive, participado da empreitada, estando presente no mencionado transporte no momento da subtração.

No primeiro grau, o magistrado julgou improcedente a ação de improbidade, por verificar que não houve a demonstração, pelo Ministério Público Federal, de qualquer ato punível pela Lei de Improbidade Administrativa, sobretudo porque os réus foram presos em flagrante, com a consequente apreensão e devolução do material dos bens aos Correios.

A sentença foi, entretanto, reformada pelo Tribunal Regional Federal da $5^{\text {a }}$ Região Apelação. Processo n. ${ }^{\circ}$ 0011078-58.2011.4.05.8300 (RECIFE, 2016). Para o colegiado, ainda que as resmas tenham sido recuperadas, a situação não afasta a incidência das condutas descritas pelo artigo 10 da Lei de Improbidade Administrativa. Os bens foram recuperados de forma involuntária, sem arrependimento posterior ou eficaz. As devoluções das resmas subtraídas ocorreram por apreensão.

Em fundamentação, a colenda turma compreendeu que esta devolução somente limita a punição dos réus. Assim, o tribunal condenou o funcionário dos Correios ao pagamento de multa de duas vezes a remuneração recebida à época.

Em sede de recurso especial, o já ex-funcionário (pois teve sua demissão em processo da esfera penal) reiterou o argumento de que os atos praticados não poderiam ser enquadrados em nenhum dos artigos da Lei de Improbidade, ensejando assim sua não condenação. A defesa do Réu "X" também destacou que não havia dano econômico a ser reparado pelo exfuncionário.

Nesse ser assim, o Superior Tribunal de Justiça, ao decidir quanto ao caso descrito acima, por meio do relatório do Ministro Benedito Gonçalves, o qual fundamentou que, em que pese os bens tenham sido reavidos, é inquestionável que os agentes retiraram o patrimônio público do seu destino e uso. Ainda estabeleceu que a recuperação do material está ligada ao ato de ressarcimento integral, mas que não apaga do mundo dos fatos o seu antecedente lógico.

Em acórdão, o Superior Tribunal de Justiça firmou o entendimento do imbróglio envolvendo os funcionários públicos e o terceiro no furto das caixas de folha sulfite. Portanto, passa-se a verificar a ementa a seguir: 
DIREITO ADMINISTRATIVO. RECURSO ESPECIAL. ATO DE IMPROBIDADE ADMINISTRATIVA FUNDAMENTADO NO ART. 10, I, DA LEI DE IMPROBIDADE. DANO AO ERÁRIO. DANO CONSUMADO NO INSTANTE EM QUE INVERTIDA A POSSE DO BEM SUBTRAÍDO DA ADMINISTRAÇÃO PÚBLICA PELO AGENTE. RECURSO ESPECIAL NÃO PROVIDO, DIVERGINDO DO MINISTRO RELATOR.

1. Na origem, o Ministério Público Federal ajuizou ação civil pública por improbidade administrativa em razão da subtração de 40 (quarenta) caixas de papel offset, tamanho A-4, do acervo da Empresa Brasileira de Correios e Telégrafos - ECT. O material subtraído foi restituído à Administração Pública, após apreensão pela Polícia Federal em estabelecimento comercial, tendo sido o réu, ora recorrente, condenado com fundamento no art. 10, I, da Lei n. 8.429/1992 (Lei de Improbidade Administrativa).

2. É inquestionável que o recorrente e os demais réus, cada um com determinado comportamento, concorreram para a subtração de 40 caixas de papel offset pertencentes à ECT, o que, inequivocamente, causou prejuízo ao patrimônio público a partir do momento em que o bem foi retirado da empresa e esteve sob a posse dos réus. A subtração das caixas de papel gerou efetiva e ilícita diminuição de patrimônio da Administração Pública e a recuperação dos bens não apaga do mundo dos fatos seu antecedente lógico, o dano ao erário, que de fato ocorreu.

3. O ressarcimento ou restituição dos bens à Administração Pública por ato daquele que praticou a conduta ímproba ou por ato de terceiro, como no caso, pode devolver o estado anterior das coisas para fins de aferição da responsabilidade pela reparação integral do prejuízo, todavia não faz desaparecer $\mathrm{o}$ ato de improbidade que gerou inicialmente o dano ao erário.

4. Recurso especial não provido.

Contrariando a hipótese aludida no início da presente análise, a devolução do bem subtraído não afasta a caracterização do ato de improbidade que cause prejuízo ao erário, entretanto, afasta a necessidade de ressarcimento ou restituição dos bens à Administração Pública por parte do agente ou de terceiro.

O afastamento da necessidade de restituição de bem já restituído para a Administração Pública se dá diante da lógica da existência do ato de improbidade, como também da vedação do enriquecimento ilícito por parte da Administração Pública. Não pode o Estado pleitear o ressarcimento de algo que já esteja novamente em posse do mesmo.

Evidente é que o prejuízo ao erário de que trata a referida legislação de combate à improbidade administrativa é visando a impedir ou punir que o agente público facilite ou concorra - em sentido amplo - para a incorporação ao patrimônio do particular, de bens integrantes do acervo patrimonial das entidades mencionadas no Art. 1. ${ }^{\circ}$ da referida lei (GAJARDONI, et al., 2014). 
Em oposição, em voto vencido, o Ministro Napoleão Nunes Maia Filho fundamentou ser possível verificar que não há possibilidade de tentativa nos atos de improbidade administrativa. Ainda, com efeito, grafou que "a apropriação do bem público não pode ser comparada ao furto, pois o tipo ímprobo tem como essência a prática de enriquecimento ilícito e de lesão aos cofres da coletividade, demandando-se a transferência duradoura e contínua do bem público para patrimônio particular” (BRASIL, 2019). Com o fato ocorreu a flagrância da prisão dos agentes motivo pelo qual nada do patrimônio público se lhes foi incorporado ou apropriado.

Contudo, o voto do Ministro Napoleão Nunes Maia Filho foi vencido, prevalecendo o entendimento que os réus sancionados não devem ressarcir a Administração Pública de um bem que não se incorporou ao patrimônio dos particulares de forma definitiva e duradoura; entretanto, devem estes agentes públicos e privados envolvidos indenizarem a empresa pública pelo ato ímprobo.

Com base na decisão do Tribunal Regional Federal da $5^{\mathrm{a}}$ Região, ficou firmada a sanção para o agente público "X", sendo considerada a conduta mais gravosa, pois exercia o cargo público, tendo como condenação o pagamento de multa no valor de duas vezes a remuneração percebida e os demais réus condenados a pagamento de metade do valor arbitrado ao primeiro.

\section{CONCLUSÃO}

A Lei de Improbidade Administrativa é importante mecanismo legislativo de combate à desonestidade, à corrupção, ao malbaratamento, aos desvios éticos, morais e, sobretudo aos ímprobos que ocorram na Administração Pública. A garantia da Ordem Pública é percorrida por todos os agentes públicos que cumprem com suas funções baseadas nos pilares principiológicos previstos constitucionalmente, quais sejam, a legalidade, a impessoalidade, a moralidade, a publicidade, a eficiência, dentre outros.

O prejuízo ao erário se caracteriza a partir do momento em que haja o vilipêndio do conjunto de recursos financeiros públicos, ou seja, nos atos que ensejem a perda patrimonial, o desvio, a apropriação, o malbaratamento ou a dilapidação dos bens ou haveres das entidades públicas. Em específico, o furto de um bem estatal, mesmo que não seja incorporado ao 
patrimônio do agente público ou privado, está profanando toda a máquina pública pelo ato ímprobo do agente.

As sanções de ressarcimento integral do dano previstas na Lei de Improbidade Administrativa devem ser levadas em consideração e aplicadas quando o bem público subtraído não for reintegrado ao patrimônio estatal, pois, caso haja devolução em tempo hábil ou a restituição compulsória do bem, não há que se falar em ressarcimento.

A aplicação de sanção de ressarcimento integral de valores resgatados ou de bens devolvidos ensejaria no enriquecimento ilícito por parte da Administração Pública. Em que pese a legislação de combate à improbidade tenha se tornado para alguns, um grande instrumento volitivo de vingança ou de arma política, não deve o poder judiciário brasileiro ingressar nesse caminho tortuoso de afronta à legalidade.

Quanto à sanção de perda dos bens e valores acrescidos ao patrimônio, incoerente seria esta, caso houvesse o ressarcimento ou devolução dos valores e bens subtraídos de forma voluntária ou até mesmo forçada. Não haveria bens a ser restituído pelo agente público ou privado que cometesse o ato de improbidade.

A devolução do bem público não descaracteriza o ato de improbidade administrativa, pois o prejuízo ao erário ocorreu no mundo dos fatos, sendo impossível sua inexistência ou descaracterização. $\mathrm{O}$ ato de improbidade nos casos em que causem dano ao erário caracterizase pela ação ou omissão, dolosa ou culposa, não sendo reconhecida sua modalidade tentada.

Somente a legitimidade da função pública ou da legalidade conferida por ato público permite a possibilidade de utilização dos bens e recursos públicos por parte dos agentes descritos em lei e, se houver qualquer outra forma não autorizada de utilização, consubstanciará em ilegalidade, ilegitimidade, improbidade e outros.

Havendo a caracterização do ato de improbidade e a devolução do bem público subtraído, seja ela por resgate via poder judiciário, seja de forma voluntária, esta deverá ser levada em consideração para fins de punição, ou seja, a devolução será fator determinante para a dosagem das sanções, de acordo com a proporcionalidade e razoabilidade do magistrado.

O agente público que subtrai bem público e por fatores pessoais ou alheios o devolve, não terá o ato de improbidade descaracterizado, mas não terá a obrigação de ressarcir os danos causados integralmente. Contudo, o ato de improbidade caracterizado enseja a sanção de perda da função pública, suspensão dos direitos políticos de cinco a oito anos, pagamento 
de multa civil de até duas vezes o valor do dano e proibição de contratar com o Poder Público ou receber benefícios ou incentivos fiscais ou creditícios, direta ou indiretamente, ainda que por intermédio de pessoa jurídica da qual seja sócio majoritário, pelo prazo de cinco anos.

\section{REFERÊNCIAS}

AMÉRICO, Lucas Carvalho; FREITAS, Francys Gomes. Análise referente à lei 8.429/92 e as sanções aplicadas por atos de improbidade administrativa: a (im)prescritibilidade nas ações de ressarcimento por ato doloso de improbidade. Direito administrativo e gestão pública I [Recurso eletrônico on-line]. Organização CONPEDI/CESUPA. Coordenadores: Edith Maria Barbosa Ramos; Arianne Brito Cal Athias. Florianópolis: CONPEDI, 2019.

AMORIM JUNIOR, Silvio Roberto Oliveira de. Improbidade administrativa: procedimento, sanções e aplicação racional. Belo Horizonte: Fórum, 2017.

BARBOSA, Alessander Santos. Improbidade administrativa por dano ao erário. São Paulo: Livrus, 2016.

BRASIL. Constituição. Constituição da República Federativa do Brasil: promulgada em 05 de outubro de 1988. Diário Oficial [da] República Federativa do Brasil, Brasília, 05 de outubro de 1988. Disponível em:

<http://www.planalto.gov.br/ccivil_03/constituicao/constituicao.htm> Acesso em $10 \mathrm{abr}$ 2020.

BRASIL. Lei n. 8.429, de 02 de junho de 1992. Dispõe sobre as sanções aplicáveis aos agentes públicos nos casos de enriquecimento ilícito no exercício de mandato, cargo, emprego ou função na administração pública direta, indireta ou fundacional e dá outras providências.

Diário Oficial [da] República Federativa do Brasil, Brasília, 02 jun 1992. Disponível em: <http://www.planalto.gov.br/ccivil_03/leis/18429.htm> Acesso em 10 abr 2020.

BRASIL. Superior Tribunal de Justiça. Recurso Especial n. 1.579.678. Relator Ministro Benedito Gonçalves. Brasília, DF, 25 de abril de 2019. Disponível em: <https://ww2.stj.jus.br/processo/revista/documento/mediado/?componente=ITA\&sequencial= $1819678 \&$ num_registro $=201600160954 \&$ data $=20190604 \&$ formato=PDF $>$ Acesso em: $14 \mathrm{abr}$ 2020.

CAPEZ, Fernando. Improbidade Administrativa - limites constitucionais. 2. ed. São Paulo: Saraiva, 2015.

DINAMARCO, Pedro da Silva. Requisitos para a procedência das ações por improbidade administrativa. In: Improbidade Administrativa Questões Polêmicas e Atuais. Coordenadores Cassio Scarpinella Bueno e Pedro Paulo de Rezende Porto Filho. São Paulo: Malheiros, 2001. 
FAZZIO JÚNIOR, Waldo. Improbidade administrativa: doutrina, legislação e jurisprudência. 4. ed. rev. atual. e ampl. São Paulo: Atlas, 2016.

FERNANDES, Karla Vaz; SILVA, Thiago Henrique Costa. A administração pública e o desvirtuamento principiológico: o uso da propina como meio de corrupção e improbidade. Direito administrativo e gestão pública I [Recurso eletrônico on-line]. Organização CONPEDI/ UNISINOS. Coordenadores: Giovani da Silva Corralo; Janaína Rigo Santin; Mateus Eduardo Siqueira Nunes Bertoncini. Florianópolis: CONPEDI, 2018. GAJARDONI, Fernando da Fonseca; et al. Comentários à Lei de Improbidade Administrativa. 3. ed. São Paulo: Revista dos Tribunais, 2014.

GARCIA, Emerson. Improbidade administrativa. 8. ed. São Paulo: Saraiva, 2014.

HARGER, Marcelo. Improbidade Administrativa: comentários à Lei n. ${ }^{\circ}$ 8.429/92. São Paulo: Atlas, 2015.

LIMA, Wellington Henrique Rocha de; FERREIRA, Jussara Borges. Mediação, conciliação e acordos nos atos de improbidade administrativa. Rio de Janeiro: Lumen Juris, 2019.

MARTINS JÚNIOR, Wallace Martins. Probidade Administrativa. São Paulo: Saraiva, 2001.

MELLO, Marcos Bernardes de. Teoria do fato jurídico: plano da existência. 22. ed. São Paulo: Saraiva Educação, 2019.

MIRANDA, Henrique Savonitti. Improbidade Administrativa. Lei no 8.429/1992. Brasília: Alumnus, 2012.

NEVES, Daniel Amorim Assumpção; OLIVEIRA, Rezende Oliveira. Manual de Improbidade Administrativa: direito material e processual. 7. ed. Rio de Janeiro: Forense; São Paulo: MÉTODO, 2019.

PAZZAGLINI FILHO, Marino. Lei de improbidade administrativa comentada: aspectos constitucionais, administrativos, civis, criminais, processuais e de responsabilidade fiscal. 7. ed. São Paulo: Atlas, 2018.

PERNAMBUCO. Justiça Federal. 10. Vara Federal. Ação Civil Pública. Processo n. ${ }^{\circ}$ 0011078-58.2011.4.05.8300. Recife, PB, 15 de agosto de 2011. Disponível em:

<https://www.jfpe.jus.br/consultaProcessos/resconsproc.asp> Acesso em: 14 abr 2020.

PERNAMBUCO. Tribunal Regional Federal da $5^{\text {a }}$ Região. Apelação. Processo n. ${ }^{\circ} 0011078-$ 58.2011.4.05.8300. Recife, PB, 21 de janeiro de 2016. Disponível em: <http://www.trf5.jus.br/cp/cp.do> Acesso em: 14 abr 2020. 